\title{
HUBUNGAN ANTARA MOTIVASI, KEDISIPLINAN, KOMPENSASI, LINGKUNGAN KERJA, DAN PERAN SUPERVISOR DENGAN KINERJA KARYAWAN PABRIK SUSU CV. CITA NASIONAL DI KABUPATEN SEMARANG JAWA TENGAH
}

\author{
RELATION AMONG MOTIVATION, DISCIPLINE, COMPENSATIONS, \\ WORK ENVIRONMENT, AND THE ROLE OF SUPERVISOR WITH \\ EMPLOYEES PERFORMANCE OF MILK FACTORY CV. CITA NASIONAL \\ IN SEMARANG DISTRICT, CENTAL JAVA
}

\author{
Astida Yussi ${ }^{1)}$ danBayu Nuswantara ${ }^{1)}$ \\ Universitas Kristen Satya Wacana \\ Email: 522014065@ student.uksw.edu
}

\begin{abstract}
ABSTRAK
Salah satu industri pengolahan susu di Jawa Tengah adalah CV. Cita Nasional berlokasi di Salatiga - Kopeng Km. 5, Kecamatan Getasan, Kabupaten Semarang. Tujuan dari penelitian ini adalah untuk menganalisis hubungan antara motivasi, disiplin, kompensasi, lingkungan kerja, dan peran pengawas dengan kinerja karyawan pabrik susu di CV. Cita Nasional. Penelitian dilakukan pada bulan April-Mei 2018. Jenis penelitian adalah deskriptif kuantitatif. Teknik pengambilan sampel menggunakan Simple Random Sampling. Responden dalam penelitian ini adalah 60 karyawan pabrik CV. Cita Nasional. Pengumpulan data diperoleh dengan wawancara, observasi, kuesioner, dan studi literatur. Teknik analisis data yang digunakan adalah Korelasi Rank Spearman. Hasil penelitian menunjukkan bahwa motivasi, disiplin, kompensasi, lingkungan kerja, dan peran pengawas memiliki hubungan positif dan signifikan dengan kinerja karyawan.
\end{abstract}

Kata kunci: motivasi, disiplin, kompensasi, lingkungan kerja, peran pengawas

\section{ABSTRACT}

One of the milk processing industries in Central Java is CV. Cita Nasional located on Salatiga-Kopeng Km. 5, Getasan District, Semarang Regency. The purpose of this study was to analyze the relation among motivation, discipline, compensation, work environment, and the role of supervisor with employees performance of milk factory in $C V$. Cita Nasional. The research was conducted in April-May 2018. The type of research is quantitative descriptive. The sampling technique uses Simple Random Sampling. Respondents in this study were 60 factory employees of $\mathrm{CV}$. Cita Nasional. Data collection was obtained by interview, observation, questionnaire, and literature study. The data analysis technique used is Rank Spearman Correlation. The results showed that motivation, discipline, compensation, work environment, and the role of supervisors had a positive and significant relationship with employees performance.

Keywords: motivation, discipline, compensation, work environment, role $f$ supervisors 


\section{PENDAHULUAN}

Susu merupakan sumber protein hewani selain daging dan telur. Susu sebagai sumber protein hewani mempunyai arti sangat penting karena susu mengandung nilai gizi yang lengkap dan tinggi. Tingginya kandungan protein, lemak, vitamin dan mineral pada susu menyebabkan usaha peningkatan konsumsi susu menjadi penting guna memperbaiki gizi masyarakat (Astuti, 2002). Pengolahan susu segar menjadi berbagai bentuk produk pada dasarnya bertujuan mencegah kerusakan susu lebih cepat atau memperpanjang umur simpan, sehingga konsumsi susu dan produk olahannya dapat lebih meluas di seluruh lapisan masyarakat dengan jumlah yang semakin meningkat.

Kinerja merupakan hasil kerja baik secara kualitas maupun kuantitas yang telah dicapai seseorang berdasarkan target yang telah ditetapkan sesuai dengan peranan dan tanggung jawab dalam perusahaan. Tidak semua kinerja terlaksana dengan baik, hal tersebut dapat disebabkan oleh beberapa faktor. Faktor-faktor yang memiliki hubungan dengan kinerja meliputi: motivasi, gaya kepemimpinan, dan disiplin kerja (Puji, 2014). Motivasi kerja merupakan suatu dorongan untuk melakukan suatu pekerjaan. Motivasi kerja erat hubungannya dengan kinerja atau performansi seseorang (Priatini, 2012). Pada dasarnya motivasi kerja pada diri seseorang itu berbeda-beda, ada yang memiliki motivasi kerja tinggi, namun juga ada yang motivasi kerjanya rendah.

Supervisor memegang peranan yang penting guna meningkatkan kinerja karyawan, salah satunya yaitu memberikan arahan kepada bawahannya apabila melakukan kesalahan. Dapat dinyatakan bahwa kemampuan supervisor memimpin bawahannya akan sangat berhubungan dengan kinerja bawahannya (Thoha, 2011).

Menurut Aritonang dalam Aditya (2010) disiplin kerja merupakan bagian dari faktor kinerja. Heidjrachman dan Husnan (2002) mengungkapkan disiplin adalah setiap perseorangan dan juga kelompok yang menjamin adanya kepatuhan terhadap perintah dan berinisiatif untuk melakukan suatu 
tindakan yang diperlukan seandainya tidak ada perintah.

Selain itu, kompensasi memiliki hubungan dengan kinerja karyawan (Hertati, 2009). Kompensasi adalah penghargaan atau ganjaran pada para pekerja yang telah memberikan kontribusi dalam mewujudkan tujuannya, melalui kegiatan yang disebut bekerja (Nawawi, 2001).

Lingkungan kerja merupakan elemen organisasi sebagai sistem sosial di dalam pembentukan perilaku individu pada organisasi. Menurut Mangkunegara dalam Fahrizal (2015) lingkungan kerja mempunyai hubungan yang sangat erat terhadap kinerja karyawan. Motif berprestasi yang perlu dimiliki oleh karyawan harus ditumbuhkan dari dalam diri sendiri dan dari lingkungan kerja, karena motif berprestasi yang ditumbuhkan dari dalam diri sendiri akan membentuk suatu kekuatan diri dan jika situasi lingkungan kerja turut menunjang maka pencapaian kinerja akan lebih mudah.

Salah satu industri
pengolahan susu di Jawa Tengah
adalah CV. Cita Nasional yang

terletak di Salatiga di Jalan Raya Salatiga-Kopeng Km. 5, Kecamatan Getasan, Kabupaten Semarang 50774. Pendirian CV Cita Nasional oleh Bapak H. Rudi Kurnia Danu Wijaya pada tanggal 10 November 2000, serta diresmikan oleh Prof. Dr. Ir. Bungaran Saragih, M.Sc. selaku Menteri Pertanian dan Perkebunan Republik Indonesia. Pada awal berdirinya, perusahaan tersebut berkomitmen untuk menghasilkan produk susu yang bermutu yang diwujudkan dengan mesin teknologi modern dari Eropa dan Amerika Serikat dan didukung oleh tenaga profesional. Selain itu dilakukan pengawasan mutu yang ketat dengan sistem Quality Control.

Produksi susu di CV. Cita Nasional dilakukan setiap hari mulai dari jam 07.00 hingga selesai dengan kapasitas susu rata-rata 16.000 20.000 liter per hari. Oleh karena itu perusahaan menuntut karyawannya bekerja penuh untuk mencapai target yang sudah ditentukan perusahaan. Hal ini pastinya sangat berhubungan dengan kinerja karyawan. Beberapa hal yang diduga berhubungan dengan kinerja karyawan di CV. Cita Nasional yaitu motivasi, 
kedisiplinan, $\quad$ kompensasi, lingkungan kerja, dan peran supervisor.

Berdasarkan latar belakang di atas dapat dirumuskan permasalahan penelitian sebagai berikut: bagaimanakah hubungan antara motivasi, kedisiplinan, kompensasi, lingkungan kerja, dan peran supervisor dengan kinerja karyawan pabrik susu? Untuk itu akan dilaksanakan penelitian terkait dengan kinerja karyawan pabrik susu di CV. Cita Nasional.

\section{METODE PENELITIAN}

Penelitian ini dilaksanakan pada bulan April-Mei 2018 selama kurang lebih 1 bulan. Tempat penelitian di CV. Cita Nasional berlokasi di Jl. Raya SalatigaKopeng KM. 5 Kec. Getasan, Kab. Semarang dengan pertimbangan CV. Cita Nasional merupakan salah satu pabrik terbesar di daerah Salatiga dengan produksi susu pasteurisasi dan homogenisasi serta yoghurt.

Jenis penelitian ini adalah deskriptif kuantitatif. Teknik pengambilan sampel penelitian ini menggunakan teknik probabilty sampling yaitu Simple Random
Sampling dengan pertimbangan karyawan yang bekerja di CV. Cita Nasional sebagian besar laki-laki, berasal dari daerah yang sama, dan rata-rata tingkat pendidikan terakhir yaitu SMA. Pengambilan sampel sebanyak 60 responden dari populasi pekerja di CV. Cita Nasional sebanyak 90 karyawan. Pengambilan sampel ini mengikuti kaidah setiap variabel bebas diwakili 10 sampel (Sugiyono, 2012). Teknik pengumpulan data yang digunakan adalah wawancara, observasi, kuesioner, dan studi pustaka. Instrumen penelitian ini yaitu menggunakan kuesioner berisi pertanyaan yang diajukan untuk responden berbentuk checklist. Skala yang digunakan untuk pengukuran yaitu skala likert. Untuk menguji pernyataan pada kuesioner digunakan Uji Validitas dan Uji Reliabilitas. Kriteria uji validitas adalah jika korelasi sudah lebih besar dari 0.3 , pertanyaan yang dibuat dikategorikan shahih/valid (Setiaji, 2004), sedangkan kriteria uji reliabitas jika Cronbach Alpha $(\alpha)>$ 0.6 maka reliabilitas pertanyaan bisa diterima (Setiaji, 2004). Teknik analaisis data untuk mengetahui 
hubungan menggunakan Korelasi

Rank Spearman.

$$
\text { Rank Spearman }
$$

merupakan alat ukur yang digunakan untuk mengukur kuat lemahnya hubungan 2 variabel yang berbeda. Nilai Rank Spearman (rs) berkisar antara $-1<$ rs $<1$. Nilai rs bisa bertanda positif maupun negatif, nilai rs dapat diinterpretasikan sebagai berikut :

1. Koefisien korelasi (rs) positif (rs $>0$ ) berarti menunjukkan hubungan yang positif atau searah, di mana kenaikan variabel $\mathrm{X}$ diikuti kenaikan variabel Y.

2. Koefisien korelasi (rs) negatif (rs < 0) berarti menunjukkan hubungan yang negatif atau terbalik, kenaikan variabel $\mathrm{X}$ diikuti oleh penurunan variabel $\mathrm{Y}$, atau penurunan variabel $\mathrm{X}$ diikuti oleh kenaikan variabel Y.

3. Koefisien korelasi ( $\mathrm{rs}=0$ ) berarti hubungan antara kedua variabel tidak memiliki hubungan.

Adapun ukuran kuatnya hubungan koefisien korelasi menurut Sugiyono (2014) adalah sebagai berikut:
Tabel 1. Keeratan Hubungan

\begin{tabular}{cc}
\hline $\begin{array}{c}\text { Interval } \\
\text { Koefisien }\end{array}$ & $\begin{array}{c}\text { Tingkat Keeratan } \\
\text { Hubungan }\end{array}$ \\
\hline $0,00-0,19$ & Sangat Lemah \\
$0,20-0,39$ & Rendah \\
$0,40-0,59$ & Sedang \\
$0,60-0,79$ & Kuat \\
$0,80-1,00$ & Sangat Kuat \\
\hline
\end{tabular}

\section{HASIL DAN PEMBAHASAN}

Hubungan Motivasi $\left(\mathrm{X}_{1}\right)$ dengan Kinerja Karyawan (Y)

Dari hasil tabel 2, dapat dilihat bahwa nilai koefisien korelasi Rank Spearman antara motivasi dengan kinerja karyawan yaitu sebesar 0,443 dengan tanda positif serta signifikan pada tingkat kepercayaan 95\%. Hal ini menunjukkan bahwa terdapat hubungan satu arah antara motivasi kerja dengan kinerja karyawan. Jika motivasi kerja tinggi, kinerja karyawan juga tinggi, namun keeratan hubungan antara keduanya hanya pada tingkat sedang di mana koefisien variabel motivasi berada pada interval $0,40-0,59$ sesuai dengan teori Sugiyono (2014) tentang kuatnya hubungan korelasi. Keeratan hubungan ini, hanya menunjukkan tingkatan hubungan antara motivasi kerja dengan kinerja karyawan. Berdasarkan hasil frekuensi jawaban responden 
menggunakan

menunjukkan bahwa bahwa karyawan selalu memotivasi dirinya sendiri untuk menyelesaikan pekerjaan sesuai dengan target perusahaan, serius bekerja walaupun kondisi lingkungan kurang mendukung, dan menjalin komunikasi yang baik dengan sesama karyawan. Hal ini sesuai dengan penelitian Priatini (2012) yang mengatakan bahwa motivasi berhubungan positif dan signifikan dengan kinerja karyawan. Motivasi dengan kinerja karyawan juga memiliki keeratan hubungan cukup kuat atau sedang. Sedangkan menurut Latief (2012) dengan terbentuknya motivasi yang baik, maka dapat membuahkan hasil atau kinerja yang baik sekaligus berkualitas dari pekerjaan yang telah dilakukan.

\section{Hubungan Kedisiplinan $\left(\mathbf{X}_{2}\right)$ dengan Kinerja Karyawan (Y)}

Dari hasil tabel 2, dapat dilihat bahwa nilai koefisien korelasi Rank Spearman antara kedisiplinan dengan kinerja karyawan yaitu sebesar 0,740 dengan tanda positif serta signifikan pada tingkat kepercayaan 95\%. Hal ini menunjukkan bahwa terdapat hubungan satu arah antara kedisiplinan dengan kinerja karyawan. Jika kedisiplinan kerja tinggi, kinerja yang berusia muda. Rendahnya pendidikan sangat karyawan juga tinggi. Selain itu, kedisiplinan memiliki keeratan hubungan yang tinggi dengan kinerja karyawan dimana koefisien variabel kedisiplinan berada pada interval $0,60-0,79$ sesuai dengan teori Sugiyono (2014) tentang kuatnya hubungan korelasi.

Tabel 2. Hasil Uji Korelasi Rank Spearman

\begin{tabular}{l}
\begin{tabular}{|l|l|c|c|l|c|}
\hline No. & \multicolumn{1}{|c|}{ Variabel } & Korelasi rs & Sig. & Keterangan & Keeratan \\
\hline 1. & Motivasi $\left(\mathrm{X}_{1}\right)$ & $0,443^{*}$ & 0,000 & Signifikan & Sedang \\
\hline 2. & Kedisiplinan $\left(\mathrm{X}_{2}\right)$ & $0,740^{*}$ & 0,000 & Signifikan & Kuat \\
\hline B. & Kompensasi $\left(\mathrm{X}_{3}\right)$ & $0,717^{*}$ & 0,000 & Signifikan & Kuat \\
\hline 4. & Lingkungan Kerja $\left(\mathrm{X}_{4}\right)$ & $0,682^{*}$ & 0,000 & Signifikan & Kuat \\
\hline 5. & Peran Supervisor $\left(\mathrm{X}_{5}\right)$ & $0,677^{*}$ & 0,000 & Signifikan & Kuat \\
\hline
\end{tabular} \\
Sumber : Data Primer Penelitian 2018 \\
\hline
\end{tabular}


Hasil frekuensi jawaban responden menggunakan kuesioner, menunjukkan bahwa karyawan di CV. Cita Nasional selalu mengutamakan kedisiplinan supaya kinerja mereka dinilai baik oleh perusahaan dilihat dari absensi karyawannya yang rata-rata tidak pernah datang terlambat. Hal ini sejalan dengan penelitian Pitria (2017) yang menyatakan bahwa disiplin kerja memiliki hubungan yang nyata dan positif serta memiliki hubungan yang kuat. Menurut Budi Setiyawan dan Waridin dalam Aditya (2010) menyatakan bahwa disiplin kerja karyawan bagian dari faktor kinerja. Disiplin kerja harus dimiliki oleh setiap karyawan dan harus dibudayakan di kalangan karyawan agar bisa mendukung tercapainya tujuan organisasi karena merupakan wujud dari kepatuhan terhadap aturan kerja dan juga sebagai tanggung jawab diri terhadap perusahaan.

\section{Hubungan Kompensasi $\left(\mathbf{X}_{3}\right)$ dengan Kinerja Karyawan (Y)}

Dari hasil tabel 2, dapat dilihat bahwa nilai koefisien korelasi Rank Spearman antara kompensasi dengan kinerja karyawan yaitu sebesar 0,717 dengan tanda positif serta signifikan pada tingkat kepercayaan 95\%. Hal ini menunjukkan bahwa terdapat hubungan satu arah antara kompensasi dengan kinerja karyawan. Jika kompensasi tinggi, kinerja karyawan juga tinggi. Selain itu, kompensasi memiliki keeratan hubungan yang tinggi dengan kinerja karyawan dimana koefisien variabel kompensasi berada pada interval $0,60-0,79$ sesuai dengan teori Sugiyono (2014) tentang kuatnya hubungan korelasi.

Berdasarkan hasil frekuensi jawaban responden menggunakan kuesioner, menunjukkan bahwa kompensasi yang diberikan oleh $\mathrm{CV}$. Cita Nasional sangatlah dibutuhkan oleh karyawan. Hal ini dapat dilihat bahwa mereka membutuhkan uang untuk memenuhi kebutuhan seharihari, selain itu karyawan juga dapat memanfaatkan dengan baik bonus dan tunjangan yang diberikan oleh perusahaan. Hal ini sejalan dengan penelitian Herdian (2010) bahwa kompensasi memiliki hubungan dengan kinerja, dimana salah satu tujuan utama karyawan bekerja 
adalah mendapatkan imbalan untuk mencukupi berbagai kebutuhan, sementara disisi perusahaan mereka membayar karyawan agar para karyawan bisa menjalankan pekerjaan sesuai dengan keinginan dan harapan perusahaan dengan tujuan utama mampu memajukan jalannya usaha perusahaan.

\section{Hubungan Lingkungan Kerja $\left(\mathrm{X}_{4}\right)$ dengan Kinerja Karyawan (Y)}

Dari hasil tabel 2, dapat dilihat bahwa nilai koefisien korelasi Rank Spearman antara lingkungan kerja dengan kinerja karyawan yaitu sebesar 0,682 dengan tanda positif serta signifikan pada tingkat kepercayaan 95\%. Hal ini menunjukkan bahwa terdapat hubungan satu arah antara lingkungan kerja dengan kinerja karyawan. Jika lingkungan kerja tinggi, kinerja karyawan juga tinggi. Selain itu, lingkungan kerja memiliki keeratan hubungan yang tinggi dengan kinerja karyawan dimana koefisien variabel lingkungan kerja berada pada interval 0,60-0,79 sesuai dengan teori Sugiyono (2014) tentang kuatnya hubungan korelasi.
Berdasarkan hasil frekuensi jawaban responden menggunakan kuesioner, menunjukkan bahwa lingkungan kerja berhubungan dengan kinerja karyawan. Oleh karena itu CV. Cita Nasional memberikan fasilitas yang mendukung guna meningkatkan kinerja karyawan seperti melengkapi ruangan dengan ventilasi agar sirkulasi udara berjalan dengan baik, perlengkapan kerja yang lengkap (topi, masker, seragam, dan sepatu boot), dan ruangan tempat bekerja dalam kondisi yang baik dan nyaman. Walaupun ruang tempat bekerja terdengar suara bising dari mesin, hal ini tidaklah mengganggu aktivitas karyawan dalam bekerja, karyawan tetap menyelesaikan pekerjaan mereka dalam kondisi tersebut. Hal ini sesuai dengan penelitian Indriani dan Madiono (2015) menyatakan bahwa lingkungan kerja berhubungan positif dan signifikan dengan kinerja karyawan.

\section{Hubungan Peran Supervisor $\left(\mathbf{X}_{\mathbf{5}}\right)$ dengan Kinerja Karyawan (Y) \\ Dari hasil tabel 2, dapat dilihat bahwa nilai koefisien korelasi}


Rank Spearman antara peran supervisor dengan kinerja karyawan yaitu sebesar 0,677 dengan tanda positif serta signifikan pada tingkat kepercayaan 95\%. Hal ini menunjukkan bahwa terdapat hubungan satu arah antara peran supervisor dengan kinerja karyawan. Jika peran supervisor tinggi, kinerja karyawan juga tinggi. Selain itu, peran supervisor memiliki keeratan hubungan yang tinggi dengan kinerja karyawan dimana koefisien variabel peran supervisor berada pada interval $0,60-0,79$ sesuai dengan teori Sugiyono (2014) tentang kuatnya hubungan korelasi.

Berdasarkan hasil frekuensi jawaban responden menggunakan kuesioner, menunjukkan bahwa supervisor sudah menjalankan tugasnya dengan baik. Hal ini dapat dilihat dari kinerja supervisor itu sendiri yaitu sudah menjalankan tugasnya dengan baik, selalu memberi dukungan, pujian maupun motivasi kepada karyawan, serta komunikasi antara karyawan dengan supervisor terjalin dengan baik. Dengan adanya perhatian yang diberikan oleh supervisor, karyawan tentunya lebih semangat dalam menyelesaikan pekerjaan sehingga kinerjanya akan lebih baik. Hal ini sesuai dengan penelitian Putri, dkk. (2014) yang menyatan bahwa peran supervisor memiliki hubungan yang kuat dengan kinerja karyawan. Menurut Thoha (2011) para supervisor bertanggung jawab atas kualitas kinerja para karyawan yang dipimpinnya. Dapat dinyatakan bahwa kemampuan supervisor untuk dapat memimpin bawahannya akan sangat mempengaruhi kinerja bawahannya.

\section{KESIMPULAN DAN SARAN KESIMPULAN}

Berdasarkan hasil analisis dan pembahasan dapat kesimpulan :

1. Motivasi memiliki hubungan yang positif dan signifikan, serta memiliki keeratan hubungan yang sedang dengan nilai 0,443 .

2. Kedisiplinan memiliki hubungan yang positif dan signifikan, serta memiliki keeratan hubungan yang kuat dengan nilai 0,740 .

3. Kompensasi memiliki hubungan yang positif dan signifikan, serta memiliki keeratan hubungan yang kuat dengan nilai 0,717 . 
4. Lingkungan Kerja memiliki hubungan yang positif dan signifikan, serta memiliki keeratan hubungan yang kuat dengan nilai 0,682 .

5. Peran supervisor memiliki hubungan yang positif dan signifikan, serta memiliki keeratan hubungan yang kuat dengan nilai 0,667 .

\section{SARAN}

Dari hasil penelitian ini, terdapat beberapa saran agar menjadi bahan masukkan sehingga dapat bermanfaat.

\section{Bagi Perusahaan}

Bahwa motivasi, kedisiplinan, kompensasi, lingkungan kerja, dan peran supervisor berhubungan dengan kinerja karyawan. Oleh karena itu CV. Cita Nasional harus mampu mempertahankan dan selalu mengarahkan kinerja karyawannya ke arah yang lebih baik.

\section{Bagi Peneliti Selanjutnya}

Untuk peneliti selanjutnya disarankan menggunakan variabelvariabel lain yang berhubungan dengan kinerja karyawan seperti : stress kerja, etika kerja, budaya organisasi, kepuasan kerja.

\section{DAFTAR PUSTAKA}

Aditya, R. 2010. Pengaruh Gaya Kepemimpinan, Motivasi, dan Disiplin Kerja terhadap Kinerja Karyawan PT. Sinar Santosa Perkasa Banjarnegara. Skripsi. Universitas Diponegoro. Semarang.

Astuti, D. 2002. Analisis Pengendalian Persediaan Bahan Baku Susu Bubuk (Studi Kasus : PT Mirota KSM Inc., Kecamatan Depok, Kabupaten Sleman, Daerah Istimewa Yogyakarta). Skripsi. Institut Pertanian Bogor. Bogor

Fahrizal, S. 2015. Pengaruh Kepemimpinan, Kompensasi dan Lingkungan Kerja Fisik terhadap Kinerja Karyawan (Studi Pada Karyawan Bagian Produksi PT. Jamu Jago Kota Semarang). Skripsi. Universitas Diponegoro. Semarang.

Heidjrachman dan Husnan. 2002. Manajemen Personalia. Badan Penerbit Fakultas Ekonomi (BPFE). Yogyakarta.

Herdian, A. 2010. Pengaruh Kompensasi Terhadap Kinerja Karyawan PT. Slamet Langgeng Purbalingga Dengan Motivasi Kerja Sebagai Variabel Intervening. Skripsi. Universitas Diponegoro. Semarang.

Hertati, D. 2009. Hubungan Kompensasi dengan Kinerja Karyawan di VICO Indonesia Company Muara Badak Kalimantan Timur. Jurnal 
Aplikasi Manajemen Vol.7 , No. 2.

Indriani, D. dan E. Madiono. 2015. Hubungan Lingkungan Kerja, Disiplin Kerja, dan Kinerja Karyawan. Jurnal Manajemen dan Kewurausahaan. 17(2).

Latief, B. 2012. Faktor-Faktor yang Melatiefmpengaruhi Kinerja Karyawan PT. Mega Mulia Servindo di Makasar. Jurnal Manajemen dan Akuntansi. $1(1)$.

Nawawi, H. 2001. Manajemen Sumber Daya Manusia. Gajah Mada University Press. Yogyakarta.

Pitria, P. 2017. Hubungan Disiplin Kerja dengan Kinerja Karyawan pada PT. Mitra Konservasi Indonesia (Cico Resort). Jurnal Manajemen. 1(1).

Priatini, A. 2012. Hubungan Motivasi dengan Kinerja Karyawan Pada PT. Aero Perdana Internusa. Skripsi. Universitas Widyatama. Bandung.

Puji, E. L. 2014. Pengaruh Motivasi, Gaya Kepemimpinan dan Disiplin Kerja Terhadap Kinerja Pegawai Pada KPPN Percontohan Jambi, Bangko dan Muara Bungo. Jurnal Organisasi dan Manajemen, 10 (2).

Putri, I.U., A, Hermani D.S., dan S. Nurseto. 2014. Analisis Pengaruh Peran Supervisor dan Pelatihan terhadap Kinerja
Tenaga Penjualan PT. Nasmoco Gombel Semarang. Jurnal. Universitas Diponegoro. Semarang.

Setiaji, B. 2004. Panduan Riset Dengan Pendekatan Kuantitatif, Program Pascasarjana UMS. Fakultas Ekonomi-UMS. Surakarta.

Sugiyono. 2012. Metode Penelitian Kuantitatif, Kualitatif, dan R\&D. Alfabeta. Bandung.

Sugiyono. 2014. Metode Penelitian Kuantitatif, Kualitatif, dan R\&D. Alfabeta. Bandung.

Thoha, M. 2011. Perilaku Organisasi: Konsep Dasar dan Aplikasinya. PT. Raja Grafindo Persada. Jakarta. 